\title{
Pengembangan Bahan Ajar Untuk Pembelajaran Matematika Bagi Siswa Tunarungu
}

\author{
Tomy Syafrudin ${ }^{1}$, Sujarwo ${ }^{2}$ \\ ${ }^{1}$ Program Studi Pendidikan Matematika, Universitas Pesantren Tinggi Darul Ulum Jombang \\ ${ }^{2}$ Program Studi Matematika, Universitas Pesantren Tinggi Darul Ulum Jombang \\ e-mail: syaf.tommy@gmail.com
}

\begin{abstract}
Abstrak. Bahan ajar yang digunakan oleh guru saat mengajar siswa tunarungu masih menggunakan bahan ajar siswa umum dan guru masih kesulitan menerapkan bahan ajar dalam proses pembelajaran, sehingga perlu adanya bahan ajar yang sesuai dengan kebutuhan dan karakteristik siswa tunarungu. Tujuan dari penelitian ini adalah mengembangkan bahan ajar matematika untuk siswa tunarungu. Metode yang digunakan adalah metode pengembangan Model Plomp dengan tahapan; Pleliminary Research, Prototyping Phase dan Assesment Phase. Penilaian dari pengembangan ini adalah valid, praktis dan efektif. Unsur yang divalidasi yaitu materi matematika, pembelajaran, bahasa, grafis, visual ketunarunguan. Unsur praktis dilihat dari kuisioner yang dilakukan guru, sedangkan unrut efektif dilihat dari kuisioner yang diberikan kepada siswa. Hasil penelitian ini adalah bahan ajar yang memenuhi kriteria valid, praktis dan efektif, sehingga dapat digunakan untuk pembelajaran matematika bagi siswa SLB Kelas XII dengan kebutuhan khusus tunarungu.
\end{abstract}

Kata Kunci : Tunarungu, Bahan Ajar, Matematika.

\begin{abstract}
Teaching materials used by teachers when teaching deaf students still use general student teaching materials and teachers still need teaching materials in the learning process, it is very necessary to have teaching materials that are appropriate to the needs and habits of deaf students. The purpose of this study is to develop mathematics teaching materials for deaf students. The method used is the Plomp Model development method with development; Preliminary Research, Prototype Phase and Assessment Phase. The assessment of this development is valid, practical and effective. Validated elements are mathematics, learning, language, graphics, visual impairment. Not practical seen from the questionnaire conducted by the teacher, while not effective seen from the questionnaire given to students. The results of this study are teaching materials that meet valid, practical and effective criteria, so that they can be used for learning mathematics for SLB Class XII students with hearing impaired special needs.
\end{abstract}

Keywords: Deaf, Teaching Material, Mathematics.

\section{PENDAHULUAN}

Anak berkebutuhan khusus yang sering disebut ABK adalah anak yang memiliki karakter dan kebutuhan berbeda dalam hal interaksi dan perlakuan. Istilah yang sering digunakan untuk kelompok ini adalah disabilitas. Disabilitas merupakan serapan kata disability dari bahasa Inggris, "the state of not being able to use parts of your body properly" (Summer, 2001, hlm. 503), yang memiliki arti istilah untuk seseorang yang tidak dapat menggunakan anggota tubuhnya secara tepat. Berdasarkan alasan tersebut ABK termasuk dalam kelompok disabilitas. Namun ada istilah lain untuk menyebut mereka dengan kata difabel. Kedua kata tersebut sudah menjadi tren di Indonesia dan keduanya terdapat di KBBI Kemdikbud. Disabilitas diartikan sebagai keadaan tidak mampu melakukan hal-hal dengan cara yang biasa. Sedangkan difabel diartikan sebagai 
penyandang cacat. Peneliti di bidang ABK meyebutkan bahwa mereka (ABK) mungkin tidak mampu melakukan sesuatu seperti orang normal, namun mereka melakukan dengan cara yang berbeda (Maftuhin, 2016). Mereka memiliki beberapa jenis ketunaan berdasarkan fisik dan juga mental. Salah satunya adalah tunarungu. Jika dikaitkan dalam dunia pendidikan, tunarungu termasuk pada siswa kelas B, siswa yang memiliki keterbatasan atau ketidakmampuan dalam berkomunikasi secara lisan dengan baik, sehingga mereka mengutamakan komunikasi tulisan dan isyarat. Hal itu menyebabkan penggunaan indera penglihatan sebagai alat komunikasi.

Pemerintah Indonesia dalam hal ini adalah Kementerian Pendidikan, telah memberikan dukungannya terhadap mereka (ABK). Sejak tahun 1991 Pemerintah telah membuat peraturan yaitu Peraturan Pemerintah RI Nomor 71 Tahun 1991 tentang Pendidikan Luar Biasa (Pemerintah Republik Indonesia, 1991). Kemudian dikembangkan dengan peraturan tentang Ujian Nasional untuk siswa ABK, tepatnya di Keputusan Presiden Nomor 77/ Tahun 2007 tentang Peraturan Menteri Pendidikan Nasional Republik Indonesia Nomor 70 Tahun 2009 tentang Pendidikan Inklusif (PENSIF) Bagi Peserta Didik Yang Memiliki Kelainan Dan Memiliki Potensi Kecerdasan dan/atau Bakat Istimewa. Pada pasal 9 ayat 2 tertulis bahwa Peserta didik yang mengikuti pembelajaran berasarkan kurikulum yang dikembangkan sesuai dengan standar nasional pendidikan atau di atas standar nasional pendidikan wajib mengikuti ujian nasional (Amra, t.t.). Berdasarkan peraturan tersebut maka ujian nasional bagi siswa berkebutuhan khusus itu wajib.

Matematika merupakan salah satu mata pelajaran yang diujikan dalam Ujian Nasional yang diselenggarkan setiap tahun untuk tingkat akhir pada masing-masing jenjang, termasuk juga bagi sekolah luar biasa. Upaya yang harus dilakukan adalah dengan memperbaiki proses pembelajaran, baik dari bahan ajar maupun pengajarnya. Bahan ajar merupakan infomasi, alat dan teks yang dibutuhkan oleh guru dalam merencanakan atau menelaah dari penerapan pembelajaran (Majid, 2008, hlm. 30).

Berdasarkan hasil studi pendahuluan di salah satu sekolah luar biasa di Jombang, ditemukan informasi bahwa buku ajar yang digunakan bukan merupakan buku yang khusus digunakan untuk siswa tunarungu (gambar 1) sehingga kurikulum yang terdapat pada buku itu tidak sesuai dengan kurikulum Pendidikan Khusus yang tertuang dalam lampiran II Peraturan Direktur Jenderal Pendidikan Dasar dan Menengah Nomor: 10/D/KR/2017 tertanggal 4 April 2017 tentang Struktur Kurikulum, Kompetensi Inti-Kompetensi Dasar, dan Pedoman Implementasi Kurikulum 2013 Pendidikan Khusus.

Padahal bahan ajar (buku ajar) memiliki peranan utama pada proses pembelajaran, karena masalah yang sering kali muncul ketika pembelajaran berkenaan dengan bahan ajar yang digunakan (Aunurrahman, 2010, hlm. 199). Gazali (2016) menyatakan bahwa salah satu kompenen penting dalam proses pembelajaran adalah bahan (materi) ajar. Hal tersebut dapat dilakukan oleh guru ketika akan melaksanakan pembelajaran ke siswa. (Cai, Kaiser, Perry, \& Wong, 2009, hlm. 26) menyatakan bahwa guru harus menyusun bahan ajar yang baik dan terstruktur sehingga proses belajar mengajar dapat terlaksana dengan student centered. Bahan ajar yang baik dan menarik dapat menciptakan proses pembelajaran yang efekti dan efisien (Soeyono, 2014), serta dapat membuat siswa lebih bersemangat dalam belajar. Suneeta (2004, hlm. 268) menyatakan bahwa sebuah text-book (bahan ajar) matematika yang baik (temasuk menarik) tidak hanya pada isi materi matematika namun juga pada proses pelaksanaan pengajaran di kelas.

Selain itu juga guru matematika di sekolah luar biasa merupakan guru mata pelajaran yang kurang memiliki keterampilan bahasa layaknya guru kelas SLB pada umumnya. Karena memang backgroundnya matematika bukan pendidikan luar biasa. Itulah yang menyebabkan pembelajaran matematika di kelas tidak berjalan maksimal. Buku ajar yang digunakan tidak sesuai kebutuhan dan karakteristik siswa tunarungu, sehingga menyebabkan guru yang masih kesulitan menerapkan buku regular ke siswa tunarungu. Disisi lain, stigma tentang matematika adalah pelajaran yang sulit, ternyata juga terjadi di sekolah luar biasa. Itulah juga menjadi rangakaian penyebab pembelajaran matematika di sekolah luar biasa tidak maksimal. 
Standarisasi kualitas sekolah luar biasa selain mengikuti Ujian Nasioan Khusus SLB, ternyata ada Olimpiade Sains Nasional (OSN). OSN merupakan olimpiade bidang sains yang dikhususkan untuk siswa SLB.Salah satu mata pelajaran yang dikompetisikan adalah matematika. Di kabupaten Jombang, masih banyak sekolah luar biasa yang tidak maksimal dalam mengikuti kegiatan tersebut, salah satunya karena siswa tunarungu tidak memiliki mendapatkan pembelajaran matematika dengan baik. Padahal siswa tunarungu bukan berarti tidak dapat mengikuti suatu kegiatan belajar dengan keterbatasan pendengarannya, melainkan dengan menggunakan atau memaksimal indera tertentu, yaitu penglihatan. Siswa tunarungu itu bisa mengikuti prosedur matematika secara simbolik dari pada hanya dijelaskan secara lisan, karena siswa tunarungu adalah siswa yang inti dalam kegiatan pembelajaran menggunakan aspek visual.

Berdasarkan uraian di atas maka diperlukan tindakan berupa pengembangan bahan ajar yang dapat membantu dan memaksimalkan proses pembelajaran matematika di sekolah luar biasa. Pada akhirnya peneliti bermaksud mengembangkan bahan ajar matematika untuk siswa sekolah luar biasa tingkat SMA.

\section{METODE}

Penelitian ini merupakan jenis penelitian pengembangan yang menggunakan model pengembangan Plomp. Tahap penelitian Plomp terdiri dari 3 tahap. Pertama, preliminary research (penelitian pendahuluan) terdiri dari proses analisis kebutuhan, meninjau berbagai literatur, mengembangkan kerangka bahan ajar. Kedua, prototyping phase (tahap membuat prototipe) yang merupakan tahap iterasi bahan ajar dalam mengembangkan bahan ajar diulang melalui evaluasi formatif sampai proses penyempurnaan berjalan sesuai tujuan, dan assessment phase (tahap asesmen) merupakan penilian akhir untuk menyimpulkan kelayakan bahan ajar melalui evaluasi sumatif. Penelitian ini dilaksanakan di salah satu sekolah luar biasa di Kabupaten Jombang, sebagai mitra (lokasi penelitian).

Prosedur Penelitan pengembangan ini dimulai dengan analisis kebutuhan tentang peserta didik, kemudian melakukan tinjauan literatur tentang bahan ajar yang digunakan dan melakukan wawancara serta memberikan kuisioner kepada guru pengajar. Selanjutnya merancang kerangka bahan ajar yang akan dikembangkan. Setelah itu, menyusun bahan ajar dari hasil perancangan konsep yang sudah ada. Bahan ajar yang telah tersusun dilakukan validasi terhadap materi matematika, unsur kebahasaan, unsur kegrafikan, unsur visual ketunarunguan dan pembelajaran. Selanjutnya hasil validasi diperbaiki dan disampaikan kepada guru pengajar untuk dilakukan uji kepraktisannya. Setelah itu dilakukan pratik pembelajaran di kelas dan mendapatkan hasil uji keefektifan.

Analisis data ini dilakukan pada tiga aspek yang disebutkan sebelumnya yaitu valid, praktis dan efektif. Kriteria valid dianalisis menggunakan rumus

$$
S_{v}=\frac{S_{r}}{S_{m}} \times 100 \%
$$

dengan:

$S_{v}$ : Prosentase rataan skor validasi

$S_{r}:$ Rataan skor validasi dari masing-masing validator

$S_{m}$ : Skor maksimal yang diperoleh

Dasar yang digunakan untuk melakukan analisis hasil validasi bahan ajar disesuaikan dengan kriteria yang telah diadaptasi dari Purbasari, Kahfi \& Yunus (2013) sebagai berikut. 
Tabel 1. Kriteria Kevalidan Bahan Ajar

\begin{tabular}{cll}
\hline \multicolumn{1}{c}{$\boldsymbol{S}_{v}$} & Kriteria & Keterangan \\
\hline $76 \% \leq S_{v} \leq 100 \%$ & Valid & Tidak perlu revisi \\
$50 \% \leq S_{v}<76 \%$ & Cukup valid & Revisi kecil \\
$26 \% \leq S_{v}<50 \%$ & kurang valid & Revisi besar \\
$0 \% \leq S_{v}<26 \%$ & Tidak valid & Tidak layak/revisi total \\
\hline
\end{tabular}

Selanjutnya, untuk menganalisis kepraktisan menggunakan rumus berikut.

$S_{p}=\frac{S_{r}}{S_{m}} \times 100 \%$

$S_{p}$ : Prosentase rataanskor

$S_{r}:$ Rataan skor

$S_{m}$ : Skor maksimal yang diperoleh

Kemudian, untuk menganalisis hasil uji kepraktisan digunakan tabel kriteria kepraktisan yang sudah diadaptasi dari Purbasari, Kahfi \& Yunus (2013) sebagai berikut.

Tabel 2. Kriteria Kepraktisan Bahan Ajar

\begin{tabular}{cc}
\hline Kriteria & Keterangan \\
\hline $76 \% \leq S_{p} \leq 100 \%$ & Bahan Ajar praktis \\
$50 \% \leq S_{p}<76 \%$ & Bahan Ajar cukup praktis \\
$26 \% \leq S_{p}<50 \%$ & Bahan Ajar kurang praktis \\
$0 \% \leq S_{p}<26 \%$ & Bahan Ajar tidak praktis \\
\hline
\end{tabular}

Sedangkan, untuk menganalisis hasil uji keefektifan digunakan rumus sebagai berikut.

$$
S_{e}=\frac{S_{r}}{S_{m}} \times 100 \%
$$

$S_{e}$ : Prosentase rataan skor

$S_{r}:$ Rataan skor

$S_{m}$ : Skor maksimal yang diperoleh

Untuk hasilnya dianalisis menggunakan tabel keefektifan yang telah diadaptasi dari Edy (2015) sebagai berikut.

Tabel 3. Kriteria respon siswa terhadap Bahan Ajar hasil adaptasi

\begin{tabular}{cc}
\hline Kriteria & keterangan \\
\hline $81 \% \leq S_{e} \leq 100 \%$ & Sangat efektif \\
$61 \% \leq S_{e}<81 \%$ & Efektif \\
$41 \% \leq S_{e}<61 \%$ & Cukup efektif \\
$21 \% \leq S_{e}<41 \%$ & Kurang efektif \\
$0 \% \leq S_{e}<21 \%$ & Tidak efektif \\
\hline
\end{tabular}

\section{HASIL DAN PEMBAHASAN}

Bahan ajar yang dikembangkan pada penelitian ini berpedoman pada pengertian yang dicantumkan oleh Depdiknas (2008, hlm. 9) bahwa bahan ajar adalah kumpulan bahan atau materi dalam segala bentuk yang digunakan untuk membantuk proses pembelajaran oleh guru kepada siswa. Dick, Carey, dan Carey (2009, hlm. 203) berpendapat bahwa bahan ajar berisi serangkaian 
materi ajar yang harus dipelajari kepada siswa melalui guru sebagai fasilitatornya, baik yang berbentuk cetak maupun tidak untuk mencapai tujuan dari rencana pembelajaran yang disusun. Materi yang dikembangkan dalamn bahan ajar ini adalah materi untuk siswa SLB tunarungu jenjang kelas XII. Bahan ajar ini berisi tokoh terkait, penerapan dalam kehidupan sehari hari, penjelasan materi yang dilengkapi dengan gambar, contoh soal dan latihan. Bahan ajar ini dikembangkan berdasarkan kebutuhan dan karakteristik siswa tunarungu yang tujuannya adalah dapat membuat siswa lebih memahami materi dan tertarik untuk belajar saat pembelajaran matematika.

Siswa tunarungu memiliki kecenderungan menggunakan bahasa isyarat, itu yang membuat proses pembelajaran matematika memiliki tingkat kesulitan sendiri. Isyarat tidak dapat mengakomodir seluruh bahasa umum (kosa kata), itulah yang menyebabkan kosa kata yang dimiliki siswa tunarungu terbatas sehingga pemahaman siswa terhadap suatu konsep terhambat (Syafrudin, 2019). Seperti yang disampaikan oleh Sugiarti (2015) bahwa siswa tunarungu memiliki keterbatasan dalam hal bahasa (kosa kata) yang menyebabkan mereka kesulitan dalam memahami konsep pelajaran. Bahan ajar ini membantu guru dalam proses pembelajaran dengan menyediakan uraian materi dan penjelasan secara secara visual, karena siswa tunarungu memiliki keterbatasan dalam hal mendengar sehingga sehingga pembelajaran harus berbasis visual dan menjelaskannya menggunakan bahasa isyarat (Sartika, 2013, hlm. 42), serta memberikan contoh-contoh kongkrit dalam kehidupan sehari-hari. Kuntze, Golos and Enns (2014), menyebutkan bahwa pendidikan yang diberikan kepada anak yang tunarungu pasti secara alamiah bersifat visual karena dia memilliki kekurangan dalam hal pendengaran. Oleh sebab itu, proses pembelajaran pembelajaran harus mengutamakan unsur visual dan konkret bahkan yang sering dijumpai, karena akan menambah koleksi kosa kata siswa tunarungu sehingga mempermudah komunikasi saat pembelajaran. Zakia, dkk (2016) menyatakan untuk siswa tunarungu dalam proses pembelajaran, jika awalnya pembelajaran bersifat abstrak maka harus diubah menjadi konkret supaya dapat dipahami oleh mereka.

Bahan ajar divalidasi oleh para ahli pada bidang masing-masing. Validasi bahan ajar ini dilakukan oleh 5 ahli berbeda. Validasi pertama dilakukan terhadap materi matematika. Validasi kedua dilakukan terhadap unsur kebahasaan. Kemudian, validasi ketiga dilakukan terdapat unsur kegrafikan. Selanjutnya untuk validasi keempat dilakukan terhadap unsur visual ketunarunguan. Terakhir validasi dilakukan terhadap unsur pembelajaran di kelas.

Tabel 4. Perolehan Skor Uji Kevalidan Bahan Ajar

\begin{tabular}{|c|c|c|c|}
\hline Aspek & $\mathbf{s}$ & $\mathrm{sm}$ & $\mathrm{Sv}(\%)$ \\
\hline Matematika & 127 & 144 & 88 \\
\hline Bahasa & 65 & 72 & 90 \\
\hline Grafis & 66 & 72 & 92 \\
\hline Pembelajaran & 67 & 72 & 93 \\
\hline Visual Ketunarunguan & 64 & 72 & 89 \\
\hline \multicolumn{3}{|c|}{ rata-rata } & 90 \\
\hline
\end{tabular}

Pada tabel 4 di atas, skor kevalidannya adalah $90 \%$ yang berdasarkan tabel 1 . kevalidan bahan ajar termasuk dalam kriteria valid, sehingga bahan ajar tersebut dapat disampaikan kepada guru untuk dilakukan uji kepraktisan. Uji kepraktisan dari bahan ajar yang dikembangkan dilakukan ketika proses pembelajaran di kelas. Perolehan hasil penilaian yang berupa data kuantitatif kemudian dikonversikan menjadi data kualitatif, sehingga dapat dikategorikan tingkat kepraktisan bahan ajar tersebut. 
Tabel 5. Perolehan Skor Uji Kepraktisan

\begin{tabular}{ccccc}
\hline Peniliai & Sr & Sm & Sp(\%) \\
\hline Observer & 37 & 40 & 92,50 \\
Guru & 36 & 41 & 87,80 \\
\hline & rata-rata & & 90,15 \\
\hline
\end{tabular}

Pada tabel 5 di atas, dapat dilihat bahwa perolehan persentase adalah 90,15\% yang saat disandingkan dengan tabel 2 kriteria kepraktisan bahan ajar termasuk dalam kriteria praktis. Selanjutnya untuk tes keefektifan didasarkan pada angket respon siswa untuk diisi. Perolehan hasil angket respon siswa dapat dilihat di tabel 6.

Tabel 6. Perolehan skor angket respon siswa

\begin{tabular}{cccc}
\hline Subjek & Sr & Sm & Sp(\%) \\
\hline Ke-1 & 35 & 48 & 72,92 \\
Ke-2 & 36 & 48 & 75,00 \\
Ke-3 & 33 & 48 & 68,75 \\
\hline & rata-rata & & 72,22 \\
\hline
\end{tabular}

Pada tabel 6 di atas, dapat diketahui bahwa persentase tingkat keefektifan adalah 72,22\% berdasarkan tabel 3, maka keefektifan bahan ajar ini termasuk kategori efektif.

Berdasarkan uji kriteria bahan ajar yang ditentukan maka pengembangan bahan ajar ini menujukkan kriteria valid, cukup praktis, dan cukup efektif. Sehingga dapat dikatakan bahwa bahan ajar ini dapat digunakan untuk kegiatan pembelajaran matematika di sekolah luar biasa untuk siswa tunarungu untuk jenjang SMA. Proses pembelajaran yang dilakukan oleh guru ketika menggunakan bahan ajar ini tetap harus dibekali kemampuan bahasa isyarat. Seperti yang disampaikan oleh Hidayat dan Suherman (2016) bahwa siswa tunarungu dalam proses pembelajaran merasa lebih nyaman jika penyampaiannya berbasis bahasa isyarat.

\section{KESIMPULAN}

Hasil dari penilitian pengembangan ini adalah buku ajar matematika yang dapat digunakan di SLB Kelas XII untuk siswa tunarungu. Bahan ajar ini telah mengakomodir kebutuhan dan karakteristik siswa tunarungu dengan mengutamakan ciri visual seperti yang dinyatakan oleh Maltzan dan Kuntze, dkk. Ciri visual tertuang dalam penjelasan materi dan contoh yang kontekstual berdasarkan pengalaman siswa, sehingga membuat siswa dapat memahami materi dan lebih menarik. Pengembangan bahan ajar ini berupa buku yang telah memenuhi kriteria valid, praktis dan efektif.

Pada saat guru menerapkan bahan ajar ini diharapkan dipahami secara mendalam karena nanti ketika mengajar dapat dikembangkan contoh-contoh yang lebih banyak lagi dan guru harus juga belajar memahami bahasa isyarat siswa, untuk memperlancar proses pembelajaran. Saran penelitian selanjutnya adalah pengembangan bahan ajar untuk materi, mata pelajaran atau kelas, atau bahkan kelas lain. Sebab, bahan ajar yang dihasilkan dari penelitian dapat lebih sesuai dengan kebutuhan siswa SLB dari pada hanya menggunakan buku yang sudah ada namun tidak sesuai dengan kriteria dan kebutuhan siswa. 


\section{PENGHARGAAN}

Penelitian ini diselenggarakan untuk mendukung pengabdian kepada masyarakat, Program Kemitraan Masyarakat dalam mengembangkan buku ajar untuk siswa tunarungu yang didanai oleh Kementerian Riset dan Teknologi Pendidikan Tinggi Republik Indonesia.

\section{DAFTAR PUSTAKA}

Amra, H. (t.t.). Dasar Hukum yang Melandasi Pendidikan bagi ABK. Diambil dari https://www.academia.edu/17887990/DASAR_HUKUM_YANG_MELANDASI_PE NDIDIKAN_BAGI_ABK

Aunurrahman. (2010). Belajar dan pembelajaran. Diambil dari https://shopee.co.id/Belajar-danpembelajaran-i.81420047.1605127223

Cai, J., Kaiser, G., Perry, B., \& Wong, N.-Y. (2009). Effective Mathematics Teaching from Teachers' Perspectives: National and Cross-National Studies. https://doi.org/10.1163/9789087908225

Depdiknas. (2008). Pengembangan Bahan Ajar dan Media. Jakarta: Departemen Pendidikan Nasional.

Dick, W., Carey, L., \& Carey, J. O. (2009). The Systematic Design of Instruction. Merrill/Pearson.

Edy, M. A. (2015). Pengembangan multimedia interaktif dengan pembelajaran berdasarkan masalab untuk meningkatkan hasil belajar materi sistem repirasi di SMAN 1 Purwosari / Mareta Arisswara Edy (Diploma, Universitas Negeri Malang). Diambil dari http://repository.um.ac.id/26665/

Gazali, R. Y. (2016). Pengembangan bahan ajar matematika untuk siswa SMP berdasarkan teori belajar ausubel. Pythagoras: Jurnal Pendidikan Matematika, 11(2), 182-192. https://doi.org/10.21831/pg.v11i2.10644

Hidayat, R., \& Suherman, S. (2016). Kemampuan Komunikasi Matematis Siswa Tunarungu Pada Pembelajaran Matematika di SMPLB-B PKK Provinsi Lampung. Jurnal Pendidikan Progresif, 6(1), 73-84.

Kuntze, M., Golos, D., \& Enns, C. (2014). Rethinking literacy: Broadening opportunities for visual learners. Sign Language Studies, 14(2), 203-224.

Maftuhin, A. (2016). Mengikat Makna Diskriminasi: Penyandang Cacat, Difabel, dan Penyandang Disabilitas. INKLUSI, 3(2). https://doi.org/10.14421/ijds.030201

Majid, A. (2008). Perencanaan pembelajaran mengembangkan standar kompetensi guru. Bandung: Remaja Rosdakarya.

Pemerintah Republik Indonesia. Pendidikan Luar Biasa. , Pub. L. No. 72, 72 (1991).

Purbasari, R. J., Kahfi, M. S., \& Yunus, M. (2013). Pengembangan aplikasi android sebagai media pembelajaran matematika pada materi dimensi tiga untuk siswa SMA kelas X. Jurnal Online Universitas Negeri Malang, 1(4), 1-10.

Sartika, Y. (2013). Ragam Media Pembelajaran ADAPTIF untuk Anak Berkebutuban Khusus. Yogyakarta: Familia.

Soeyono, Y. (2014). Pengembangan Bahan Ajar Matematika dengan Pendekatan Open-ended untuk Meningkatkan Kemampuan Berpikir Kritis dan Kreatif Siswa SMA. Pythagoras: Jurnal Pendidikan Matematika, 9(2), 205-218. https://doi.org/10.21831/pg.v9i2.9081

Sugiarti, S. (2015). Upaya Meningkatkan Kosa Kata Anak Tunarungu Melalui Media Variasi Gambar Pada Siswa Kelas V/B di SLB Negeri Surakarta. PROSIDING SEMINAR NASIONAL PENDIDIKAN, 7. Surakarta: Kerjasama Program Studi S-3 Ilmu Pendidikan, Program Studi S-2 Pendidikan Luar Biasa Universitas Sebelas Maret Surakarta dan ISPI Wilayah Jawa Tengah.

Summer, D. (2001). Longman Dictionary of Contemporary English. Diambil dari https://www.academia.edu/12456745/Longman_Dictionary_of_Contemporary_English _4th_ed.

Suneetha, E. (2004). Methods of Teaching Mathematics. Discovery Publishing House Pvt. Limited. 
Syafrudin, T. (2019). Proses Berpikir Siswa Tunarungu Dalam Menyelesaikan Masalah Matematika. Dipresentasikan pada Seminar Nasional Pendidikan dan Ilmu Matematika "Gerak Lincah Pembelajaran Matematika di Era Intelegensi Semu," Malang.

Zakia, D. L., Sunardi, S., \& Yamtinah, S. (2016). Pemilihan dan Penggunaan Media dalam Pembelajaran IPA Siswa Tunarungu Kelas XI Di Kabupaten Sukoharjo. Sainsmat : Jurnal Ilmiah Ilmu Pengetabuan Alam, 5(1). https://doi.org/10.35580/sainsmat5130452016 